\title{
Linking ICT and society in early warning and adaptation to hydrological extremes in mountains
}

\author{
C. de Jong \\ Mountain Centre, University of Savoy, Le Bourget du Lac, 73376, France \\ Correspondence to: C. de Jong (dejong.carmen@neuf.fr) \\ Received: 6 June 2012 - Published in Nat. Hazards Earth Syst. Sci. Discuss.: \\ Revised: 18 November 2012 - Accepted: 29 November 2012 - Published: 13 September 2013
}

\begin{abstract}
The assessment of the societal impact of hydrological extremes is particularly important in mountain regions, since mountains can be considered both as the generators and victims of extreme events. ICT can provide a powerful tool for transmitting hydro-meteorological information to predict, prepare and adapt to such events. However, in remote regions, such as mountains, the poles, deserts and islands, preventive and adaptive measures are often restricted by data availability and lack and/or incoherence of data networks. This paper distinguishes between early warning of floods and droughts, emphasising the latter in particular in mountains and explores the possibilities of enhancing the role of society in data collection, the identification, activation and application of stakeholder knowledge and transferral of data from gauged to ungauged catchments.
\end{abstract}

\section{Introduction}

According to Güvenen (2012), we can observe an exponentially increasing impact of knowledge and Information and Communication Technologies (ICT) on education, science, technology and decision systems. Early Warning of - and adaptation to - hydrological extremes is becoming increasingly important in inner and outer mountain regions, not only due to the impacts of climate change but also because of anthropogenic pressures. The development of methods linking ICT with society for Early Warning and adaptation to extremes should become a priority in order to increase their efficiency. This is not a trivial task since mountain catchments are often data sparse or data poor. In addition, there is a disequilibrium in the attention given to extremes. Most focus is placed on floods but droughts, low flow conditions and water scarcity have been more or less neglected, even though this is an increasing problem in dispersed Mediterranean mountains and Alps (de Jong et al., 2012; de Jong, 2009b; EEA, 2009b). From a damage perspective, droughts often cause greater economic loss than floods.

Compared to lowland areas, the density of meteorological, hydrological and water quality stations is much lower and more vulnerable to data interruptions. In general, the higher the altitude, the lower the density of measurements in most catchments. This situation is further exacerbated by the discontinuation of many long-term meteorological and discharge gauging stations by meteorological and hydrological services in mountain regions in the last decade, mostly due to financial and logistical constraints. With few new ones being established, it may become increasingly important to involve society and foundations in political and funding issues to ensure sufficient data input into research. For example, regular hydro-meteorological readings could be taken by local inhabitants and local communities could be persuaded to cofinance and maintain certain measuring equipment. This has already been the case during history, but is often forgotten. Until the First World War, the functioning of meteorological networks in some European countries was far cheaper than nowadays because many meteorological stations were maintained on a voluntary basis by teachers, clergy and other interested persons.

Depending on their geographical location (for example dry inner alpine valley or high mountain desert) mountain regions are effected more strongly and frequently by extreme events. Since 2002, there has been a major shift in precipitation and discharge regimes in the European Alps. The six hottest summers over the past $500 \mathrm{yr}$ have all been concentrated in only 9 yr after 2002 (Barriopedro et al., 2011; de 


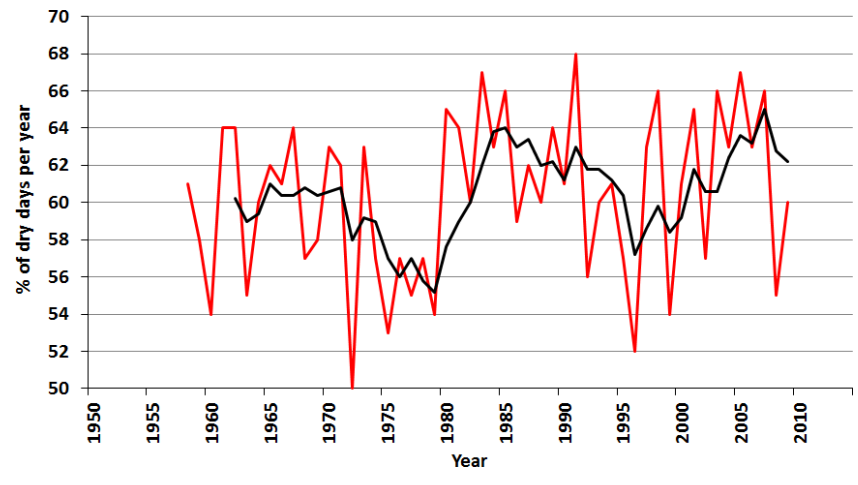

Fig. 1. Changes in the percentage of dry days per year over the last $50 \mathrm{yr}$ (red line) with 5-yr moving average (black line) for the Piemonte region (data from APRA Piemonte). Although not included in the graph, data for the year 2011 reached the higest values over the last $50 \mathrm{yr}$.

Jong and Biedler, 2012). According to the EEA, there has been an overlap in the area covered by the main drought events between 2000 and 2009 in the Alps (EEA, 2010). The number of drought days has also been growing in most of the Alps within the last $50 \mathrm{yr}$ (Casty et al., 2005; de Jong, 2012). Similarly, Brunetti et al. (2006) demonstrate that there is a general drying trend over the Greater Alpine Region of approximately $2 \%$ per century mainly caused by drier summer and autumn seasons. This trend is particularly strongly developed in the southern sub-regions. Between 1958 and 2011, which includes the 2011 drought year, there was a nearly 2 -week increase to the average number of dry days (days with less than $1 \mathrm{~mm}$ of rainfall per day) per year in Piemonte, Italy (Fig. 1 and ARPA Piemonte, 2012). Spring and autumn have also become warmer and drier than average over the past $10 \mathrm{yr}$, influencing the snowmelt regime and groundwater levels. The result has been widespread water scarcity, not confined to the lowlands but also present in mountain catchments, with far-reaching impacts on hydropower, industrial cooling water, agricultural irrigation and seasonal tourism. Successive summer droughts have led to repeated drying of mountain springs even above $1000 \mathrm{~m}$ in Upper Savoy, France (A.-M. Gizard, personal communication, 2011), in particular in geologically sensitive areas such as karst. Spring 2011 was the driest in the last $50 \mathrm{yr}$ for several alpine countries, with some of the lowest river levels recorded in the last $100 \mathrm{yr}$ in the Danube and Rhône and for the last $70 \mathrm{yr}$ for the Rhine (WMO, 2012). In 2011, Lake Constance recorded the lowest level since the onset of measurements.

Similarly, in the Alps there have been several major floods in different parts during the last decades (e.g. in 2000, 2005 and 2007), EEA (2010). Many of these extreme events are tightly interlaced in rapid temporal succession and subject to significant seasonal shifts. In consequence, important adjustments are required in dam reservoir management strategies, water provision for tourist resorts, maximum altitude

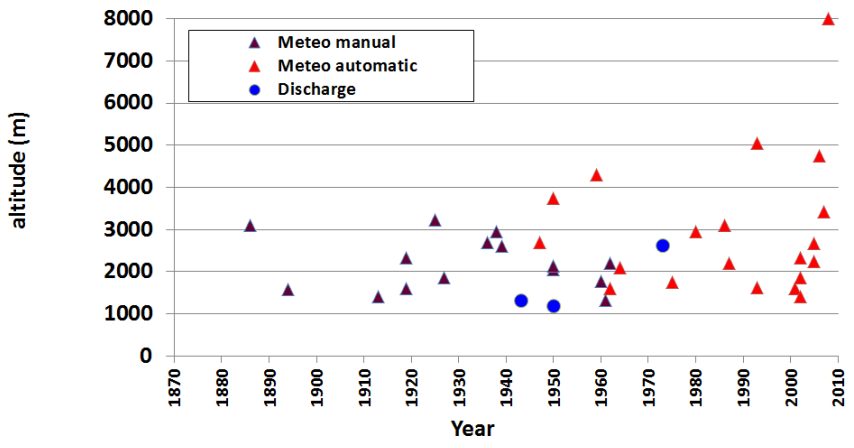

Fig. 2. Relation between beginning of manual and automatic meteorological measurements at high altitude meteorological stations (all above $1300 \mathrm{~m}$ ) world-wide: Alps, Massif Central, Anatolia, Caucasus, Altai, Himalaya, Canadian and US Rockies, Owyhee Mountains (USA) and Rwenzori Range (Africa). The two discharge stations are Vernagt Glacier (Austria) and Piave (Italy).

of irrigation, pasture cycles, as well as wood and sediment management (de Jong, 2012). It is important to realize how to involve local water users and consult the public, including tourists, but also to raise awareness on evolving issues and to initiate or ameliorate water management using a multisectorial, multi-lingual and multidisciplinary approach via ICT.

This should involve the combination of classical internetbased techniques including both the media, targeted think tank groups exchanging knowledge across different states in combination with non-ICT methods such as public debates, information and training days dedicated to policy makers and technicians, local and regional interviews and questionnaires.

The role of mountain topography, geology and mountain climatology in creating extreme floods (rainfall- or snowmelt-induced) and their vulnerability to droughts is not yet emphasized sufficiently in high resolution digital terrain models, electronic data bases and hydro-meteorological models. Furthermore, few attempts are made to develop ICT that links water with sediment transport during floods. Despite the fact that the greatest damage by floods is caused by sediments and not by water, up to present, no ICT is available for sediment predictions.

\section{Limitations of ICT in mountains}

Few mountain catchments exist that have been investigated and well instrumented over long time periods (e.g. $75 \mathrm{yr}$ and more), (Fig. 2, Marty and Meister, 2012; Serquet et al., 2011), which is an important pre-requisite for ICT in early warning and adaptation to extremes. This is mainly due to difficult logistics and high costs involved. Unfortunately, society and politicians have become accustomed to this situation, especially in terms of planning and adaptation, and rather than trying to improve the ICT basis, many 
policy-makers prefer to continue business-as-usual. In order to provide precise predictions, a good knowledge of past variations is necessary. In the context of ICT, this poses a problem, since either long term measuring data is missing or where available on paper, it has not yet been transformed into electronic form. Where measuring data is unavailable, other types of data which can be of use for early warning and adaptation can be assembled, such as dendrochronogical, archaeological, historical and geomorphological data.

Moreover, there is a clear lack of studies carried out at higher elevations and very few study sites have an average catchment elevation above $4000 \mathrm{~m}$ (de Jong et al., 2005). Most study basins are smaller than $100 \mathrm{~km}^{2}$. Even in catchments with maximum elevations around $3000 \mathrm{~m}$, most meteorological stations have been installed on valley floors below $1500 \mathrm{~m}$ and it is estimated that there are only $650 \mathrm{au}-$ tomatic weather stations worldwide above $2500 \mathrm{~m}$ (Tartari et al., 2009). However, there has been a recent trend (since the mid-1990s) to install meteorological stations at elevations above $2000 \mathrm{~m}$ (Fig. 2). Most of these have been set up in the frame of the SHARE (Stations at High Altitude for Research on the Environment) programme supported by the Italian Ev-K2-CNR committee (Tartari et al., 2009), mainly in the Hindu Kush - Karakorum - Himalaya region, in the Italian Alps but also in Africa. Although some automatic measurements started in the 1940s (Weisfluhjoch in Switzerland), most did not begin with automatic recordings before the 1980s.

The highest measuring station worldwide was set up at the South Col in a pass between Everest and Lhotse in the Himalayas (Nepal) at $8000 \mathrm{~m}$ in 2009 (SHARE, 2012). Though interrupted for a year, it began functioning again in 2011. Other high altitude meteorological stations include the Pyramid at $5050 \mathrm{~m}$ in the Khumbu Valley next to Mt. Everest (Nepal) since 1993, Urdukas on a lateral moraine of the Baltoro glacier of the Pakistan-Karakorum region at $4022 \mathrm{~m}$ since 2004 and Tingri (Tibet) at $4302 \mathrm{~m}$ since 1959 (amongst a dozen stations between 4480-5039 m) (Bertolani et al., 2000; Tartari et al., 2009; Wu et al., 2012).

In the Alps, high altitude, long term, automatic meteorological monitoring sites are limited to the Sonnblick (3105 m) in Austria, the Zugspitze (2962 m) in Germany and Weissfluhjoch $(2690 \mathrm{~m})$ in Switzerland. Important measurement series are also available at Saentis $(2502 \mathrm{~m})$, however without snow measurements for the Jungfraujoch ( $3580 \mathrm{~m}$ ) and with snow measurements only since 2007 at the Grosser St. Bernard $(2472 \mathrm{~m})$, all unanimously located in Switzerland (Marty and Meister, 2012). Whereas manual measurements started as early as 1886, 1938 and 1936 (mainly for measuring snow heights) at the Sonnblick, Zugspitze and Weissfluhjoch, automatic measurements only commenced in the 1986, 1980s and 1947, respectively. In the Val d'Aosta valley (Italy), meteorological measurements, including snow measurements, exist at the Lago Gabiet $(2340 \mathrm{~m})$, d'Ejola (1850 m), Gressonay Saint Jean (1400 m) and Gressonay La
Trinié (1631 m) since 1919, 1927, 1913 and 1916, respectively (with some interruptions), in digital form. No longterm measurements exist in France or Slovenia at comparable altitudes. The Bigorre Meteorological Observatory at $2887 \mathrm{~m}$ in the Pic de Midi (French Pyrenees) started measurements in 1878 but was closed in 1984. The Mount Aigoual (1571 m) in the Massif Central (France) has had measurements since 1894. There are no long-term measurements in the French Alps. For the remaining Alps, individual, manual measurement series exist for snow depth in various locations. It would be a valuable task to identify and digitize this data to make it available for ICT-based Early Warning Systems.

In the Canadian Rockies, automatic meteorological measurements started in 1962 at Marmot Creek $(1600 \mathrm{~m})$, followed by Peyto Glacier $(2200 \mathrm{~m}$ ) in 1987 (although other intensive measurements began in the 1960s), Wolf Creek $(1615 \mathrm{~m})$ in 1993 and more recently Lake O'Hara $(2250 \mathrm{~m})$ in 2005 (Fountain and Tangborn, 1985; Hopkinson and Young, 1998; IP3 Research Basins, 2012). In the USA, Nivot Ridge D-1 (3739 m) in the Rockies and Reynolds Creek Experimental Watershed $(2097 \mathrm{~m})$ with continuous measurements since 1950 and 1964 are amongst the most well-known measuring sites (Robins et al., 1965; Williams et al., 1996). In the Andes there are more than 30 automatic weather stations above $2000 \mathrm{~m}$, several of these lying above 4000 and even $5000 \mathrm{~m}$ (Tartari et al., 2009).

In Russia, meteorological measurements began at the end of the 19th century in the Ural and Altai mountains. In the Russian Altai mountains, the meteorological stations KaraTyurek (2600 m) have had data since 1939, Akkem (2056 m) since 1950 and Aktru $(2110 \mathrm{~m})$ started in 1958 but stopped in 1994 (Shahgedanova et al., 2010). In the Mongolian Altai, none of the meteorological stations lie in the mountains, but in the foothills between 1320 and $1780 \mathrm{~m}$ with measurement since the 1960s. In the Urals, most are at low altitudes such as the Polar Ural Salekhard weather station $(35 \mathrm{~m})$ with observations since 1883 (Mazepa et al., 2012) and Vorkuta (180 m).

In Africa, the Mt. Rwenzori (4750 m) station in the Rwenzori Range in Uganda was installed in 2006 (SHARE, Vuillermoz et al., 2009). The only other high altitude station, installed in 2001 is located at $3850 \mathrm{~m}$ on the M'Goun in the High Atlas, Morocco (IMPETUS, 2012).

Similar problems of lack of high altitude sites and longterm monitoring concern discharge measurements, although the density of discharge stations in alpine catchments is higher than for meteorological stations. Even though the WMO recommends the highest density of discharge in mountain regions, they usually have the lowest density, i.e. only one third of the recommended density (Wohl, 2000). The highest long-term discharge station in the Alps is located at $2640 \mathrm{~m}$ at the Vernagt Glacier (Austria) and started measurements in 1973 next to the automatic weather station. As for meteorological stations, there is an inverse relation between long-term measurements and altitude. Still, long-term 
measurements demonstrating the impact of climate change remain extremely rare.

Sites that have been monitored for longer periods show some clear-cut changes in hydro-meteorology world-wide, both at the annual, seasonal and at the event scale. Nevertheless, most research focus is put on floods rather than droughts and low flow conditions. Overall, the impact of climate change is causing shifts in precipitation extremes, concerning both precipitation intensity and inversely, the number of precipitation-free days per year. Resulting shifts in the frequency, magnitude and length of high- and low flow, including floods and droughts as well as seasonal shifts in overall discharge, are occurring in mountain chains worldwide (IPCC, 2012). Those regions that have experienced a longer growing season and a shift from snow to rain in the last few decades will react with earlier spring runoff and a lower runoff ratio (discharge/precipitation), (Botter et al., 2010; EEA 2009b; de Jong et al., 2009; Hunsaker et al., 2012; Koboltschnig et al., 2009; Lapp et al., 2005; Yilmaz and Imteaz, 2011).

Long-term discharge measurements of snow-fed regimes of the Piave River at Boite, Podestagno (1320 m a.s.l.) in the Italian Alps, Region of Veneto that began in 1938 and were automated in 1992, show a significant shift in annual discharge patterns from approximately 1993 onwards (Rampazzo and Vecellio, 2011 and Veneto Regional Agency). Discharge decreases by approximately $25 \%$ during the winter months due to decreased snowmelt as a result of decreased snowfall, and 30-40\% during the summer months due to decreased rainfall. In contrast, autumn discharge seems to be increasing, caused primarily by an increase in autumn floods due to a shift in precipitation.

In glaciarized regimes, discharge has been affected mainly during the summer months. Whereas a short-term increase in summer discharge is to be expected for the next years due to more intensive glacier melt during hot summers, the volume of this surplus discharge is rapidly decreasing in many smaller alpine catchments. Once snowmelt has terminated in early summer, smaller rivers (with catchments of $<5 \mathrm{~km}^{2}$ ) are predicted to develop very low flow from the beginning of July onwards. They are projected to run completely dry during the summer months from mid-August to beginning of September once mountain glaciers have disappeared or decayed to a size where they are no longer influential on the discharge regime (Koboltschnig et al., 2009). Thus glacierfed summer discharge is expected to become very vulnerable in future decades, assuming that summer precipitation from rainfall is negligible and that storage from glaciers is reduced or absent.

In the Canadian Rockies, glaciers such as the Mistaya contribute significantly to streamflow during periods that would otherwise be in a state of low flow (Demuth and Pietroniro, 2003). During some drought years this can contribute to more than $50 \%$ of the flow (G. Young, personal communication, 2011). Long-term series since the 1950s of the Bow River at
Banff (1200 m) show significant negative trends in mean and minimum flow for the transition to base flow period, thus August, September and October, defined as a period where glacier meltwater is nominally the most significant contributor to headwater streamflow (Demuth and Pietroniro, 2003; Hopkinson and Young, 1998).

On the other hand, maximum discharge has increased in these glacierized basins in association with long-term reductions in the glacier firn pack that have amplified the diurnal fluctuations of discharge and reduced the lag times associated with meltwater production from high alpine sources (Demuth and Pietoniro, 2003). Glaciers can act as a source of disturbance during intense precipitation events, for example when rain-on-ice persists for several days causing extreme flow events. Streamflow variability has increased also from these glaciarised basins since the mid-1900s in association with decreasing glacier cover. Other temperate mountain glaciers also show an extended period of maximum seasonal discharge.

Globally, the data base of scientific mountain observations and measurements is very restricted. There must be more efforts in order to link the potential demands of ICT for improved protection and early warning with ongoing scientific research. Quantitative and qualitative data are required from many different disciplines and sectors. The role of information management and human influences in hydrology has to be considered more strongly (Jones et al., 2012). Management and decision making is very complicated in catchments with strong human influences, since traditionally, natural sciences are ICT-based, whereas social sciences are less ICTand grid-based. They often depend on other kinds of data collection (not automated) using different methods and approaches, such as questionnaires and publishing narrativestyle stories. Therefore it is not sufficient to rely on meteorological stations alone for early warning and recommendations for adaptation to extreme events. Scientists require local knowledge, including descriptions of situations and development of weather phenomena and unrecorded or unexpected secondary developments. With this respect it has been recognised that indigenous knowledge is also a valuable resource to assess the effects of climate change on the people and the landscape (Hermann-Mercer et al., 2011).

Within the context of Early Warning and predictions, their requirement, feasibility and practicability have to be considered with respect to the meteorological conditions, geographical setting, infrastructural, demographic and economic properties. This is even more important in the context of adaptation to new and changing phenomena, where past and existing adaptation strategies have to be surveyed, described, understood and if possible quantified spatially and temporally and across national boundaries in similar cultural settings.

It is important first of all to differentiate between the two main hydrological extremes: floods and droughts, since the nature of their development and efforts to predict them are very different. 


\section{Early Warning of extreme events}

Early Warning of extreme events in mountain regions is restricted mainly to floods. Very little has been accomplished on droughts. In order to distinguish between the two phenomena, it is important to consider the context, characteristics and predictability of both phenomena separately.

\subsection{Floods}

Floods are valley-confined phenomena (Fig. 3), generated in catchment headwaters, often restricted in space and time. They are characterised as phenomena that develop rapidly and then persist over a specific time span, either over only a few hours, as in common in mountain environments, or over several days and weeks, as is common in the lower and flatter parts of the catchments. Floods are produced by a dominant trigger, usually intense and persistent precipitation, interacting with topography, geomorphology, soils, vegetation, geology and groundwater as well as urban and river engineering characteristics of the catchment. Their beginning and end can be defined more clearly, making it easier to monitor via ICT. Floods can be generated in several catchments simultaneously over larger regions, e.g. at the scale of a whole country, or for example the whole of Europe, but they can also be restricted to only one catchment due to specific weather conditions, such as stagnating rain clouds, hail or snowmelt stalling over a specific area, or moraine or ice-dammed lake drainage. Floods are usually propagated along small tributaries, over fans and along the valley floors. Their approximate level of flooding can be predicted reasonably well quantitatively, unless there are many man-made constructions and deviations, whose temporal and spatial reactivity may be difficult to anticipate (flooding along preferred impermeable paths and barriers, such as roads, embankments, road tunnels etc). The impacts of sediment transport may be more difficult to predict due to uncertainties in the quantity, composition and size of material as well as the areas of erosion and deposition. In particular in modified landscapes subject to river rectification processes, sediment deposition areas may be unusual, e.g. along roads within towns, industrial sites, gardens etc.

Measurement, monitoring and modelling of floods is well advanced, although limited in mountain areas, where logistical difficulties and the rapidity and complexity of floods make it more difficult to understand and predict them. Because of the known damage caused by floods, both in terms of economic, human or livestock loss, Early Warning Systems against floods are increasingly developed and applied, in particular with respect to more densely and urbanised areas. They are mostly based on simple relations between flow depth and progression along the ascending limb of the flood hydrograph with relation to bankful flow. A flood alert is usually issued when flow is close to bankful discharge and imminent overflow into the floodplain.

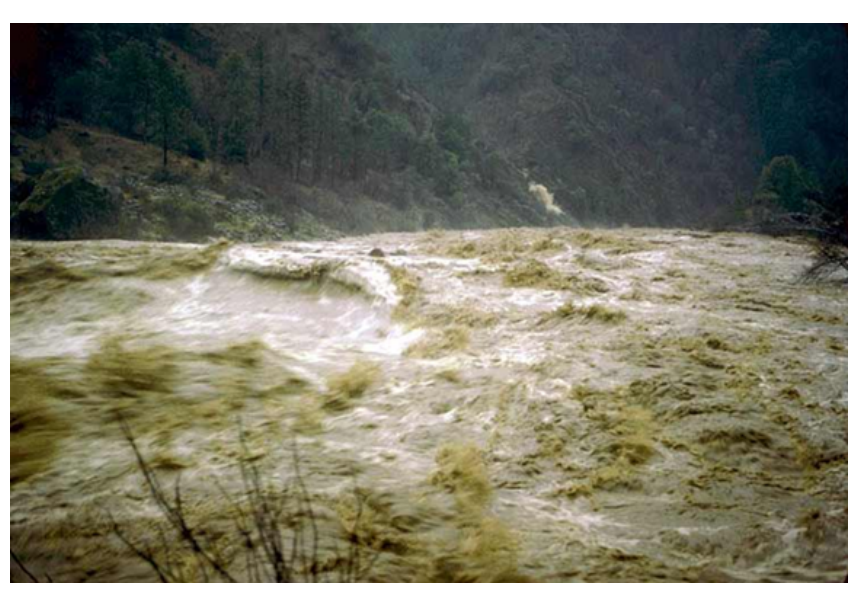

Fig. 3. Example of valley-confined flood in the Swiss Alps.

In particular within the context of climate change, Early Warning Systems are becoming more and more of a necessity as a first step towards adapting to or mitigating extremes, as the frequency and the magnitude of damageable floods is increasing in many parts of the world, and may become even more frequent under global warming (Allamano et al., 2009). For the Swiss Alps, the modelling results of the authors predict that the return period of the 100-yr flood discharge will be reduced to about $20 \mathrm{yr}$ (becoming five times more frequent) under the hypothesis of a $2{ }^{\circ} \mathrm{C}$ temperature increase and of $10 \%$ increase in the precipitation intensity, with possible relevant consequences on high-elevation ecosystems and anthroposystems. The variability of the flood return period ratio could be easily obtained also in regions with scarce data availability, by using a simple morpho-climatic model that produces scenarios using only a digital elevation model and basic precipitation data. Since the model is conceived for regional application in ungauged mountainous basins, it has to be capable of working without calibration. This was tested in 57 different basins. It is therefore suitable for application in other scarcely gauged mountainous areas of the world (see Sect. 4.1).

Predicting the characteristics of extreme events such as floods for Early Warning remains difficult since the prognosis of the tail distribution of a flood wave is usually more difficult than the onset of a flood. Often there is a lack of knowledge concerning the rapidity of response in a catchment, in particular in ungauged catchments (de Jong et al., 2012). The evolution of a flood event under modified conditions may also be difficult to predict, limiting the spectrum of possible adaption.

\subsection{Droughts}

In contrast, droughts are much more difficult to predict since they are not limited to valley floors but spread across whole regions and countries, with impacts not only across a limited period of time but effecting different zones and different 
economic sectors over different time steps and over different types (hydrological, meteorological, pedological, vegetation drought and/or water scarcity). The onset of a drought may be estimated according to the prevailing environmental conditions yet the overall length is subject to a high degree of uncertainty and their duration may be several orders of magnitude higher than for floods. For mountain regions, flood forecasting is quite well advanced, however, drought forecasting is still in its infancy since soil moisture and snow water equivalent indices do not cover mountains such as the Alps, Pyrenees and Carpathians. The soil moisture anomalies used by the European Drought Observatory of the JRC (Joint Research Centre) for drought forecasting do not cover mountains, neither does the SWE (snow water equivalent) calculated from the NASA Earth Observatory. There are some regional exceptions. For example in the frame of DEWETRA (2012), five categories of soil moisture, from very dry to saturated, as well as snow cover are included covering the entire Italian Alps. It is a real-time integrated system of risk forecasting, monitoring and prevention designed by scientists of the CIMA foundation on behalf of the Italian Civil Protection Department. Its multi-layer Graphical User Interface (GUI) can provide decision makers with high resolution and rapid refresh information of the expected and observed risk. This combination of research and operational expertise in hydrometeorology and intensive use of new technologies has brought CIMA Foundation closer to the ICT community (Parodi et al., 2010).

Droughts have to be defined in different ways according to the stakeholders involved, for example from local communes, tourism, agriculture or hydropower. In the Alps, winter droughts are more likely to induce different water uses and conflicts because of the many sectors of water uses involved and the lack of monitoring and measurement (de Jong, 2009c; EEA, 2009a, b; Soboll and Schmude, 2011). Problems of water scarcity in association with overconsumption for household use and artificial snow production in winter ski resorts have become particularly problematic during spring and winter droughts over the past $5-10 \mathrm{yr}$ (de Jong, 2009c; Hill, 2011). During winter droughts in ski resorts, drinking water may have to be obtained via groundwater or even via lorries or bottled water when surface water is insufficient and/or has been overexploited. On the other hand, mountain farmers are more dependent on direct precipitation inputs and surface flow for the success of their harvest or quality of pasture and may have little alternative during droughts apart from geographically specific irrigation. The definition and agreement of when a drought begins, when a drought warning should begin and when it should be implemented varies according to the stakeholders groups involved and their economic importance. For example, if ski tourists arrive at the beginning of a winter drought, no drought warning is issued and no awareness raising is carried out concerning water shortage and the necessity of water economies or limitations. The same applied for water transfers for artificial snow making, which increase during periods of winter drought. Farmers and citizens on the other hand are asked to decrease their water consumption during such drought periods.

\section{Enhancing the role of qualitative data in ICT}

The low density of scientific measurements is already mentioned in the introduction but where quantitative data is missing, different types of soft or qualitative data can be collected in order to improve the understanding and predictability of extreme events. In addition, much precious information can be obtained from the experience and memory of local stakeholders concerning the onset and finish, timing, magnitude, spatial distribution and peculiarities of droughtor flood-related phenomena. For droughts in particular, divergences in agriculture, timing of transhumance, provision of hay where pastures are too dry, quality of milk, state of forests, soils, animal behaviour, water levels or drying of springs and streams and water levels in snow-making reservoirs can be noted. Experienced fishers are amongst the most important drought witnesses available. Other qualitative data for droughts include dendrochronology (e.g. for the reconstruction of drought frequency and duration) and indictors for low river levels (such as dry river banks, lacking vegetation growth, exposed roots etc). For floods this includes scars on trees caused by flood and debris flow sediments, sedimentary deposits along channel and valley sides, dendrochronology (for reconstruction of flood and avalanches magnitude and frequency), use of dendrochronology to reconstruct tree age on older river terraces, and mapping of inundated areas to reconstruct the flood wave.

\subsection{Dealing with ungauged catchments}

Since many mountain catchments are ungauged, it is important to develop methods for transferring data from gauged to ungauged catchments in those cases where the catchments resemble each other climatologically, geologically or geomorphologically. So far, stakeholders are not involved enough as climate change witnesses to fill scientific knowledge gaps and inversely, not enough scientific advancements are shared with stakeholders. Scientists should become more proactive in providing knowledge for water practitioners in ungauged river basins (de Jong, 2012).

Where discharge and precipitation data is missing, Early Warning for floods can be enhanced by reconstructing an existing flood event or a catalogue of past flood events with the help of stakeholders. Thus the flood hydrograph, including its ascending limb, peak discharge and its descending limb can be systematically reconstructed from stakeholder knowledge, photos and videos concerning the approximate timing, level and area of flooded land. In urbanised areas, flood indicators 
can be obtained relatively easily. Where videos are available, the flow velocity can be estimated.

Early Warning for droughts is much more complicated in ungauged mountain basins. One of the most important parameters to obtain is snow cover. In many major Mediterranean rivers, at least $30 \%$ of the discharge is derived from snowmelt (Table 5.2, compiled by 30 authors in de Jong et al., 2012). Thus, if the SWE (snow water equivalent) is properly evaluated, more precise predictions can be made on the amount, or lack of snowmelt discharge in spring and early summer. Although the amount of snow is well registered over mountain areas via satellite images, the main problem is that the SWE is not available for mountain areas since it cannot be calculated. In the standard data bases such as NASA it is lacking, due to the difficulties in determining snow density and snow properties and validating these in remote and unmonitored basins. Long-term evolution of precipitation in the Mediterranean basin shows that for most mountainous regions, there has been a substantial decrease (up to $150 \mathrm{~mm}$ ) in the last $52 \mathrm{yr}$ (Garcia-Ruiz et al., 2011). This means that most mountain areas are under stronger stress due to lacking precipitation and will be more prone to summer and winter droughts.

\subsection{Integrating society and stakeholder knowledge}

Maintenance or expansion of scientific observations is often too expensive under alpine conditions. As a solution, the involvement of society in directed data collection should be encouraged. A lot can be learned from history, and even more than one hundred years ago, Forel (1895) and Brueckner (1907) integrated stakeholder knowledge into their glacier observations, in an era prior to the onset of meteorological observations. Forel (1895) mentions under his chapter "Witnesses" "En consultant les souvenirs des montagnards voisins du glacier, on obtient souvent des renseignements intéressants sur les dates critiques des variations de longueur, sur les époques du dernier maximum ou du dernier minimum. Une enquête intelligente donne souvent des résultats précieux" (by consulting the memory of mountain people living near glaciers, one often obtains interesting information on critical dates of variations in the length, on the timing of the last maximum or the last minimum. An intelligent interview often gives precious results). Similarly, in the Dauphiné, French Alps, Brueckner (1907) mentions: "Parcourant en toussens le Val Gaudemar et le Val Champoléon depuis 1850, Mr. David Martin a noté une foule de faits très intéressants et recueilli, de la bouche des vieillards, il y a un demisiècle, e nombreux témoignages très précieux pour l'histoire des variations glaciaires que nous résumons ci-après". (Traversing the Val Gaudemat and the Val Champoleon since 1850, David Martin has noted plenty of very interesting facts and has collected, from the mouths of elderly people from half a century ago, numerous and very precious witnesses for the history of glacial variations that we summarize here). Forel points out that the quality of the information gathered depends on how the natural scientists can strengthen the information from one witness to the next, how to extract correct and certain conclusions. Information such as the first time appearance of rocks no longer covered by glacier ice were retained.

Nowadays a combination of methods should be developed for identifying, activating and applying stakeholder knowledge, both from their past and present experience but also for their future projections. It goes without saying that caution should be taken on reliability of observations. Nevertheless the experience of stakeholders with relation to longterm data should be integrated. For floods, this could include eye-witness reports on the maximum extend of annual valley flooding, in particular where viable precipitation data is unavailable. For droughts, as mentioned in the introduction to this section, this could include historical weather trends as experienced by ranchers and accounts of the timing of the switching on of their irrigation systems in accordance with the prevailing meteorological conditions (de Jong et al., 2012b). It could also include accounts of unusual drying of sources and wells not recorded before in human memory, in particular by farmers and owners of alpine huts e.g. in Upper Savoy, French Alps 2011 (A.-M. Gizard, personal communication, 2011), Hautes Alpes (observations de Jong) and Austrian Alps (M. Falk, personal communication, 2012). Reports on the timing and frequency of water transport by trucks or tractors for drinking water supply to mountain villages in the southern Italian Alps (Scalet and Pergher, 2010) and to mountain alps to water cattle when sources have dried are valuable. The same is true for accounts on the timing and frequency of transport of bottled water when drinking water has ceased in tourist resorts due to winter droughts and water overconsumption. Stakeholder knowledge can become particularly useful when related to socio-economic interactions with climate change. Future projections are often extremely difficult when there is a highly fluctuating tourist fluctuation and water demand is unknown during drought periods. Stakeholders involved in this sector can help guiding future scenarios.

These qualitative data can be transformed into quantitative data estimates to facilitate the description of droughts and water scarcity.

Nevertheless, integrating local and scientific knowledge in environmental management remains a complex task (Raymond et al., 2010). The authors argue that no single optimum approach for integrating these different knowledge types exists. They propose a shift in science from the development of knowledge integration products to the development of problem-focussed, knowledge integration processes. Instead of one standard approach, Raymond et al. (2010) discuss the need to develop systematic, reflexive and cyclic processes that are relevant to a specific environmental management problem, allowing for multiple views and methods. 


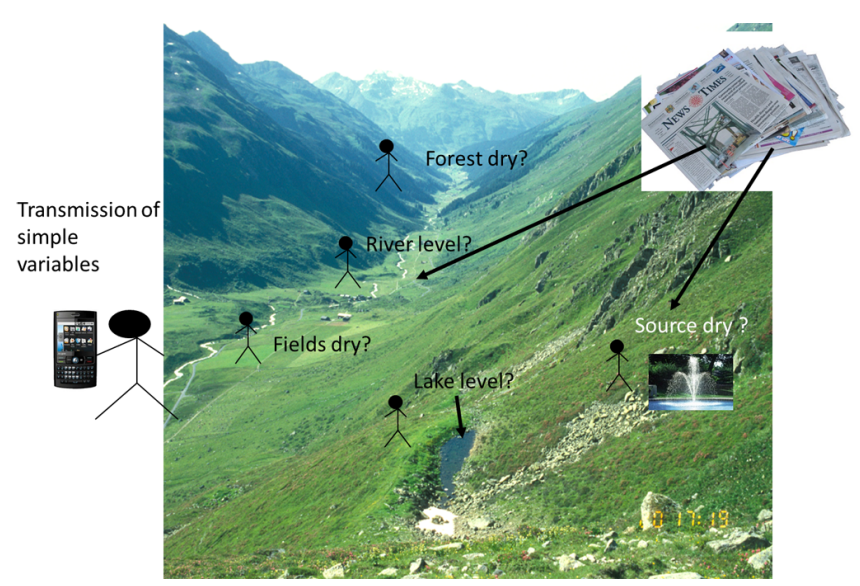

Fig. 4. Involving stakeholders in drought forecasting and as "climate change witnesses". Stakeholders can contribute to describing different natural characteristics such as presence or absence of springs and running tap water, lake and river levels, state of fields and forests. Local newspapers can act as archives. The variables could be transmitted via mobile phone.

\subsection{Awareness of climate change}

It is important to investigate how climate change is dealt with amongst stakeholders and where this is still weak or absent, awareness raising on climate change should be carried out by scientists. In this context the role of stakeholders as "climate change witnesses" should be supported. For droughts this can include observations on frequency, timing and duration of drying of springs, torrents and rivers, water levels in rivers and lakes (Fig. 4), snow depths in winter, the onset of highly evaporative winds, migration dates and behaviour of fauna, blooming and physiological characteristics of flora, quality and volume of hay harvest or occurrence of new species at high altitudes. In his book on Weather Hindcast (Pfister, 1999) uses very similar descriptions by local stakeholders to define the degree and extent of droughts e.g. concerning the severe autumn drought of 1531 "By the end of September, the weather became very dry, so that people suffered badly in the country (Switzerland) and had to walk for 3-4 hours to southern Alsace to grind their flour since all the rivers had become so small" (i.e. water levels had dropped too low) "the grains in the fields could not become green due to the drought". In other reports, the fact is mentioned that "the leaves of trees in forests dried up, the harvest failed and the fruit rotted on the trees and fell off (autumn drought of 1623)".

For floods this can include maximum flood height and extent, change in fish species, changes in river bed morphology and sediments. Observations of stakeholders via photography and observations from obvious landmarks during the course of a flood can be valuable for reconstructing the timing and extend of a flood (Fig. 5).

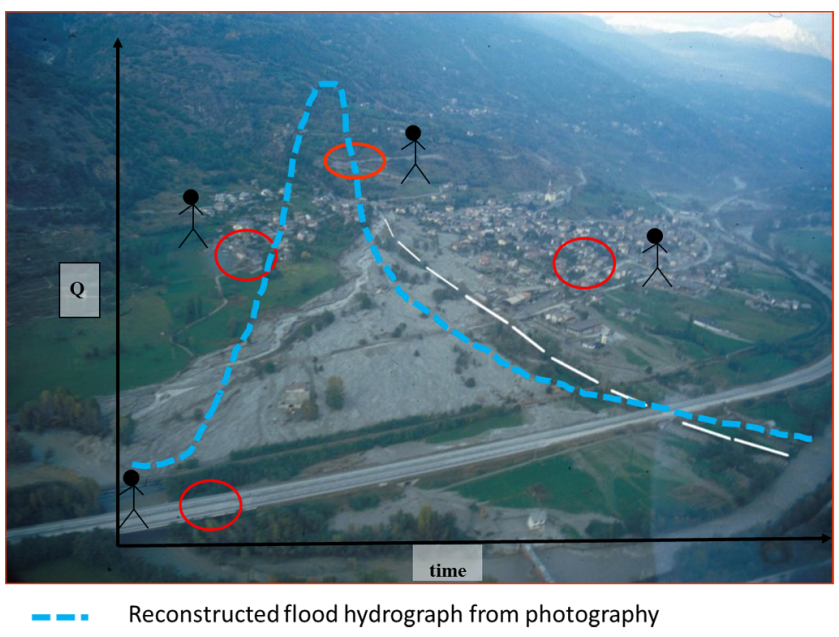

Fig. 5. Possible reconstruction of the various stages of a flood hydrograph in the Alps via stakeholder knowledge. Stakeholders can be involved by producing photos and observations from tributaries and flood plains in areas with clear landmarks during the course of a flood.

In the Swiss Alps, case studies showed that stakeholders had mixed attitudes towards climatic impacts and focused almost entirely on maintaining the status quo of winter tourism, through technical or marketing measures (Hill et al., 2010). Since the main technical measures are artificial snow production and therefore very water-intensive within the catchment, particularly during winter droughts, this issue should be an integral part of climate change awareness. However, the stakeholders in the studies ranked the integration of possible risks of climate change in the decision process as very low (Hill et al., 2010). According to Hill (2010), the results of stakeholder questionnaires showed that "the projected increase in pressure on rivers and streams arising from conflicting demands coupled with variability and seasonality changes is not receiving much attention, or being looked at as a holistic issue at the local and cantonal level". This is partially a reflection of the scientific alpine research which is more focussed on climate change and technical issues rather than being tuned to the need of policy makers through a more prescriptive policy approach (Hill et al., 2010). Another major shortcoming leading to a lack in awareness on water issues is the fact that data concerning tourism water demand are recorded neither by official nor unofficial statistics in the Alps in general (Soboll and Schmude, 2011). Therefore "a comprehensive and collaborative planning approach is vital to enable policy makers and stakeholders to maximize opportunities, minimize the adverse effects of climate change on the local economy, and develop inclusive adaptation measures that benefit the entire region in order to create more sustainable social, economic and environmental structures" (Hill et al., 2010, p. 1752). 
Traditional alpine communities may have a reluctance to change behaviour or collaborate. In this context it would be important to support pioneer stakeholders to break down barriers to change behaviour (Hill et al., 2010). Learning expeditions to other alpine areas to build knowledge and experience amongst local actors would also be an asset (Hill et al., 2010).

Current rates and type of change have meant that a more concerted effort must be placed on creating and enabling environment for adaptive capacity to accelerating rates of change in today's more complex and interconnected world (Hill, 2011).

\section{Adaptation to hydrological extremes}

\subsection{Adaptation and maladaptation to floods}

The increasing frequency of natural flood events and the increasing modification of flood hydrographs though manmade interventions in flood-producing catchments and on river courses requires a stronger adaptation. Adaptation to floods is dependent on both technical and behavioural solutions.

Although technical solutions may protect from small to medium-scale events, there is usually no risk-free protection from extreme events, as was shown for the sequence of extreme flood events in Europe in 2002. Extreme events become even more problematic when unforeseen combinations develop simultaneously, such as sudden snowmelt due to warm and dry foehn winds in winter, rain-on-snow events, combined debris-flow flood events or combined natural and man-made flood phenomena, such as intense rainfall inducing excessive melt of artificial snow in catchments subject to intensive skiing. Structural weaknesses are likely to develop with relation to extreme floods and impacts of urbanisation, e.g. water seeping from behind dikes, torrents and rivers overtopping dikes in curved positions or propagation of artificial flood waves due to domino effects of emergency water release from series of small dams. New pathways followed by extreme floods and their speed of flow are particularly unpredictable in the built environment, e.g. when flooding urbanised fans and entering tunnels, canals or flowing along roads.

Through history and before the advent of ICT, inhabitants have adapted to perturbations in the hydrological regime such as increased frequency and magnitude of floods for example, by moving away from river banks (such as along the Rhône) onto safer, higher lying regions (Wiegandt, 2008; Wiegandt and Lugon, 2008).

Although adaptation may range from temporary to permanent evacuation, the trend nowadays is to combine technical solutions with temporary evacuation. This may cause negative feed-back loops, since engineering solutions are often preferred in high risk areas rather than behavioural and decisional solutions such as the refusal of construction licenses. The need for early warning and temporary evacuation will therefore increase in the future.

Nowadays, with the wide palette of opportunities offered via ICT, communicating floods to stakeholders is easier, but not always efficient. Practitioners often prefer the application of simple warning methods (e.g. telephone) to the internet. If adaptation is to be efficient for society and civil protection, management issues (such as hydro-peaking and emergency dam release during floods) have to be included in the hydrological models. Data transfer within transboundary catchments must be optimised but the linguistic and software barriers need to be overcome first. The transfer of the final product in terms of a specific flood warning via ICT should be less of an obstacle.

\subsection{Success and constraints of adaptation to droughts}

\subsubsection{Policies for adaptation to droughts}

At the European level, there are few activities and policies dealing with adaptation to climate change that address droughts, water scarcity, and energy or water issues (de Jong and Biedler, 2012). Even less focus is put on the Alps or other European mountain chains. Among them, the EU Climate Change White Paper sets a legal framework to deal with future climate change challenges and to define an EU strategy for climate change. The White Paper recognises that "information and communication technologies (ICT) support methods, models, data sets and prediction tools for understanding and forecasting climate impact, in identifying vulnerabilities and in developing appropriate adaptation measures" but admits that "these tools require further development" (Commission of the European Communities, 2009). It further states that vulnerability should be assessed against a wide range of climate scenarios and on different geographical scales so that adaptation measures can be defined as precisely as possible. This is a challenge when facing nonhomogenous mountain terrain. The Commission intends to improve the monitoring of impacts and adaptation measures in order to develop vulnerability indicators. It indicates an urgent need for more quantitative information on the costs and benefits of adaptation. When translated into mountain areas, this type of information is even more difficult to obtain and transfer.

According to the European Commission, although a considerable amount of information and research already exists on adaptation to climate change, it is not shared across the European Member States (Commission of the European Communities, 2009). It suggests improving knowledge management by establishing an EU-wide Clearing House Mechanism as an IT tool and database on climate change impact, vulnerability and best practices on adaptation. The information system would be fed by geographical information from, for example, the Global Monitoring for Environment and 
Security (GMES), the Droughts Observatory, the European Forest Fire Information System and EuroHeat (a heat-wave probability tool).

The most relevant upcoming publication in Europe is the EU Blueprint Communication, a Blue Print for Safeguarding European Waters, that is scheduled for November 2012 and is intended to include a policy review for water scarcity and droughts. The Blueprint communication will be based on the results of an on-going analysis of the WFD's river basin management plans, giving information on how Member States have improved their water management. The 2007 policy on water scarcity and drought is reviewed, including water efficiency measures, the evolution of water resources such as water's vulnerability to climate change and man-made pressures. In addition, the outcome of the fitness check of the EU freshwater policy will be presented. This is a gap analysis to identify any uncovered areas and assess the adequacy of the current framework (European Commission, 2012). Since Europe's water security is vulnerable, it is vital that policies keep up to date and promote and integrate the experience of effected and concerned stakeholders.

One organisation tackling such issues of droughts and adaptation to climate change is the European Water Partnership (EWP, 2012) via its European Dialogue Platform. Supported by the European Commission, it carried out a stakeholder consultation on policy options and recommendations for droughts and water scarcity as a contribution to the Blueprint Communication. The EWP contributes directly to the EU Blueprint Communication via its Dialogue Platform on Climate Change Adaptation, Water and Energy. The platform and steering committee focus on the linkage between the energy and water sectors experiencing increasing water scarcity and resulting adaptation measures (de Jong and Biedler, 2012). Updated views, recommendations and challenges from both public and private sector actors dealing with energy-water related issues are included. The EWP launched a stakeholder survey targeting the private sector, NGOs, government bodies and academia representing the water, energy, agriculture, forestry, tourism, and urban sectors. Key issues identified included negative impacts of climate change on cash-flow and assets, unsatisfactory policy and implementation, and a need for more knowledge and data on climate change issues. Most respondents had not calculated the costs of adaptation or were only planning to implement adaptation measures. Financial and political constraints were identified as barriers to implementation.

In this context, a pioneer of adaptation to potential water scarcity is the town of Villach in Austria (Wasser App, 2012). The town is attempting to reduce its water consumption. The local inhabitants can monitor their household water consumption on their mobile phones. Their average water consumption is compared graphically to the national average. This creates awareness on water demand and can lead to a change in habits in the long run. It is the first alpine town to have applied this procedure.
In future, it will become important to develop frameworks for improving drought risk management and to identify breaking points in the system. One recently created climate adaptation platform is Climate-Adapt of the EEA. According to the EEA (2010, p. 25), Drought Management Plans based on the characterisation of possible droughts in a basin, their effect, and possible mitigation measures, should be prepared on a river basin scale and before emergency schemes have to be applied. Measures to prevent and alleviate the consequences of droughts and water scarcity should aim to establish a drought-resilient society with a focus on reducing the demand for water so that negative impacts of droughts on the status of water bodies are avoided. Criteria for minimum ecological flow and assuring good quantitative status for groundwater should be established (Poff et al., 2010). Furthermore, the 2010 EEA report recommends that additional water supply infrastructures such as water storage, water transfers or use of alternative sources should only be considered when other demand options have been exhausted. It also underlines the benefits of water reuse and rainwater harvesting since this effectively increases the available water resources and minimises wastewater outflow. Within the EU, wastewater reuse could supply $2 \%$ of irrigation needs by 2025 and $3.5 \%$ in Mediterranean countries. So far, this concept has not been applied to the tourism sector.

\subsubsection{Constraints of adaptation to droughts}

Adaptation to droughts requires ICT-based early warning systems as well as options for technological and behavioural change, both in the short and long term. Such options should optimally be presented in two to three simple scenarios. However, it is not possible to expect adaptation to extreme events by permanent and non-permanent inhabitants on the basis of ICT alone. An important part of the process encompasses awareness raising, building trust between scientists and stakeholders, changing mentalities and bringing stakeholders to change habits.

Even if Early Warning Systems against droughts are still uncommon in mountains, not all those that were designed are successful, mainly due to problems of empowerment between scientists and policy makers. A failed example of an ICT-based, alpine-wide characterisation of droughts and water scarcity for Early Warning can be followed over the course of the Alp-Water-Scarce project (Water Management Strategies against Water Scarcity in the Alps, 2008-2011), (de Jong, 2008a, b, 2009b). The project was initiated and coordinated by the author for the first two years but the author was prevented from pursuing the project despite international protests because the author's positions were not conform with industrial interests and because unfortunately, decisions are too often taken within a context of conflicts of interest.

This project considered both naturally caused droughts and man-made water scarcity. Strong involvement of 
stakeholders was anticipated in order to define water scarcity and water problems in the Alps and to express problems and possible solutions concerning water scarcity in questionnaires in order to improve water management strategies in the part of the Alps concerned by stakeholders. The project was one of the few interregional alpine space projects led by an applied scientific organisation.

As part of the adaptation process in the project, stakeholders were to be made aware of the emergence of different water scarcity zones and periods. Depending on data availability and length of measurement series, different levels of early warning systems were to be applied for predicting water shortage. Methods of mitigating or adapting to water scarcity problems were to be tested e.g. by improved water efficiency and water re-use. Finally, stakeholders and end-users were to obtain recommendations and suggestions for resource conflict management and mitigation measures.

A Stakeholder Interaction Forum was created in 2008 at the beginning of the project to define water scarcity and water problems at the international, national and regional scale with different stakeholders involved in the water sector based on a project-related website, electronic newsletters and workshops (de Jong, 2008b, 2009b). The forum anticipated helping with the synthesis of water problems related to water scarcity in different regions. It was also intended to undertake an exchange and transnational comparison of best practices for different states and nations in watershed management and planning. Part of the Stakeholder Interaction Forum was internet-based (via web-based questionnaires, questions and answers) and part was based on questionnaires in the field and public debates. Apart from the internet, the forum was to accompany the entire project and establish an effective communication network, closely linked to the press and media. In an era of internet and digital accesses, experience showed that electronic media provided a very effective means for rapid information transfer and constructive feedback from local stakeholders.

During the course of the project, it became evident that an electronic forum on its own was insufficient to enable smooth communication between the different stakeholder groups and project manager or partners, since not all mountain communities have internet access or available time to answer the questions on their own (de Jong, 2009a). Face-to-face interviews and telephone calls were considerably more efficient and effective. The real asset of ICT was the conversion of qualitative data into quantitative data, its processing and redistribution to the local and regional stakeholders who had been directly involved in the surveys. In this context, ICT contributes as a tool or guidance for a participative process, but can only be used in conjunction with public meetings. In the absence of proper coordination focussed on clear aims that are regularly revised and personal engagement (such as meetings and debates), this process cannot be successful (de Jong, 2009a and ICT-Ensure, 2012).
Experience showed that the implementation and choice of adaptation to hydrological extremes via ICT is not limited to a web-based tool but is inherently influenced by politics and policies. At an early stage in the project, the political influence on the choice of stakeholders was already extremely strong, thus overriding the initial aim of involving a wide palette of stakeholders and any interested person from the general public via ICT tools. Attempts were made by local departmental governments, who were project partners, to remove representatives from non-economical and nonindustrial interest groups such as fishers and environmental lawyers from the list of web-based questionnaires recommended by the scientific project coordinator in line with experience and state-of-the-art literature. However, according to AWARE (2011b), when making the choice of stakeholders it is important to create a balance between low interest and low influence, low interest and high influence, high interest and low influence and high interest and high influence stakeholder groups. In this case the high interest, low influence groups were those that were most willing but most difficult to integrate due to political reasons.

The Stakeholder Forum began by functioning at three different levels, based primarily on the feedback from questionnaires on water scarcity: the regional level at the scale of pilot areas; the national level, where a national responsible coordinated the pilot-scale information in the corresponding country and translated a synthesise of the national information into English; and the alpine level which synthesised the information by transforming qualitative data into quantitative data at the alpine scale, back-translated the results into the corresponding national languages and communicated the results to the different partners. The partners would then have been responsible for communicating the summarized information to the authorities and stakeholders involved in water management at the regional scale to benefit from the transalpine examples. Such communication to decision makers was difficult, since firstly, some of the scientific partners resisted communicating with stakeholders since this was thought of as "unscientific"; secondly, there was a lack in political will by some of the political partners to communicate the results; and thirdly, decision makers were not ready to accept the results.

One of the main outcomes of the stakeholder questionnaires was that more than $70 \%$ of the stakeholders throughout the alpine space had experienced water scarcity in one form or the other in the past and present and thought that it would be likely that they would be confronted with it in the future. They indicated that the main sectors touched by water scarcity were tourism (including artificial snow production), drinking water, forest, hydropower and agriculture. Most agreed that water scarcity was primarily due to naturally limited water resources, water quality problems, but also lacking water management (including user conflicts) and inadequate water infrastructure. However, there was a strong discrepancy in the perception of water scarcity. The higher 
the degree of involvement in decision-making spheres, the more water resources were perceived as abundant and the more water scarcity problems were downplayed. The lower the degree in decision-making and the more confronted by actual water problems, the more realistic the view on water resources and water scarcity experienced.

In 2010, after the removal of the project coordinator, the Stakeholder Interaction Forum became dormant and subsequently all ICT and public participative activities concerning the forum were discontinued. The internet link for stakeholders to access the questionnaires was deleted (www. alpwaterscarce.eu/stakeholders). The institutional homepage of the scientific coordinator was already deleted in 2009 preventing communication with stakeholders, partners and the media. Although a repeat questionnaire was carried out in 2011, it did not target the same stakeholders and important questions concerning the nature and onset of water scarcity were omitted, so that comparison with the original questions was no longer possible and the potential evolution of awareness and mentality change could not be monitored. Since some changes were subtle, ICT was an appropriate tool to recognise omissions. The results did show that whereas $30 \%$ of the answers concerning water scarcity were attributed to tourism, drinking water and artificial snow production in 2009 , this figure had risen to nearly $50 \%$ by 2011 . This more recent phenomena of water scarcity resulting from the winter tourism sector is mainly linked to winter droughts and water over-use. However, despite these important outcomes, the issue of tourism and the participation of stakeholders via the Stakeholder Interaction Forum were no longer discussed in the final recommendations.

\subsection{The stakeholder-scientist dilemma}

Despite the benefits of ICT, the gap between scientific and institutional topics is getting wider due to different processing speeds and interests. The weight of scientists in linking ICT with practice, awareness raising and policy making should become much stronger. This will require scientists not only to become more strongly involved in public service but also to keep continually updated on current water- and climate related issues, track changing mentalities of citizens, enlarge their multi-disciplinary horizon, trim complexity and learn how to generalize. Some of these issues were suggested by policy makers in the context of natural hazards at the Great Debate of the EGU (2012). Scientists should become more proactive in providing tailored knowledge for water practitioners in river basins, both via ICT and direct dialogue.

Currently, not enough scientific advancement is shared with stakeholders, and vice versa; stakeholders are only rarely involved as climate change witnesses to fill scientific knowledge gaps (de Jong, 2012). It is important to involve stakeholders continuously in the research and adaptation process to hydrological extremes in the Alps, in particular where data is scarce or non-existent. For example, the way should be paved for identifying experienced, key stakeholders to give presentations at applied scientific conferences (de Jong, 2012). Ideally such stakeholders should take part regularly in both applied and scientific international alpine conferences and events, to be able to attain a highly informed approach. Good practice examples of spontaneous adaptation to extreme events should be identified, even in remote areas and successful adaptation techniques from the past used to inspire the future. Unforeseen chain effects linked via hydrology and meteorology to agriculture, tourism and industry are to be anticipated, such as the impacts of droughts on local and regional economy. Whilst the focus should be placed on local level implementation, lessons learned should also be fed back into European level policies (AWARE, 2011a).

\subsection{Availability and limitations of ICT tools for adaptation}

There are several other limitations of ICT closely related to adaptation, such as incompatibilities encountered at the interfaces between qualitative and quantitative information and data systems and problems of integrating "routine" (quantitative) versus "non-routine" (mostly non-quantitative) data (de Jong, 2009a; de Jong and Maurer, 2010). Improvements could be made in developing simplifications and shortcuts for converting qualitative data in an objective way to quantitative data. This would require integration of socio-economic experts and stakeholders confronted with every-day issues of hydrological extremes. Another major problem in multilingual mountain ranges is the linguistic barrier at the local scale. Many stakeholders do not master English and are therefore exempt from using ICT. Other limitations are that ICT usually deals with hydrological extremes as neatly defined "closed systems" rather "open systems". There can also be implementation problems of ICT, even where it exists and is functioning, due to lack in awareness, homogenisation and application procedures.

It is recommended that ICT is applied actively rather than passively when carrying out adaptation. This requires permanent personnel responsible for the maintenance of ICT systems. All sectors of society should be accustomed to the use of ICT, including citizens involved in climate and hydrological observations, and not just top level managers and planners.

Awareness can be fostered through the ICT-based "Collective Awareness Platforms for Sustainability and Social Innovation". These platforms are a new objective in the EU FP7 ICT work programme 2013 addressing the digital social innovation emerging from the network effect and addressed to researchers, innovators or entrepreneurs through multiple different instruments. They include many interdisciplinary issues including resource scarcity.

When modelling the vulnerability of Europe's water resources and the degree of stress of water exploitation index, reference is made to digital databases such as Climwatadapt. 
The project deals with modelling water scenarios and sectorial impacts in the context of climate adaptation. However, the scale and resolution of the models are too coarse for the Alps to allow recommendations for adaptation specific to mountain environments at the highly heterogeneous catchment and valley scale. Furthermore, information is rarely available at high enough temporal resolutions (e.g. monthly, daily) and information describing the socio-economic impacts of water scarcity and drought as well as the costeffectiveness of potential measures of adaptation is either limited or not accessible across Europe (EEA, 2009a).

One tool developed to serve as the single entry point for water information in Europe is the Water Information System for Europe (WISE, 2012). Information describing water resources can both be fed into and obtained from it. Again, the tool is not very efficient for mountain areas due to lack of data, limits of scale and inefficiency of prediction.

Another example is WaterDiss2.0 (2012, see references), whose general objective is to speed up the transfer of research outputs to water management institutions (a basin authority or a city) with a targeted time lag of 3-5 yr. Cited from the project homepage of Waterdiss "When considering the impact of research on water management practices, it is demonstrated that the connection between research and the policy process is not efficient". As stated by FUNDETEC (2012), a FP6-project, final report in December 2007, "the typical length of time needed to complete the development cycle (in the water sector) is $10 \mathrm{yr}$; this means that research commissioned today will impact water management practices within about $12 \mathrm{yr}$, far after the next milestones of the Water Framework Directive $(2015,2021)$ ". Although information on about 60 water-related FP6/FP7 research projects outputs is being collected and their potential future analysed in close collaboration with the research teams, only 2 of these refer to mountain areas. The detailed objectives are to develop a water research transfer and dissemination service dedicated to researchers to promote their work and ensure it reaches the operational area and to practitioners to access the appropriate tools/methods to fulfil their needs. The project will make wide use of e-infrastructure to help stakeholders meet and share ideas. This is a mix of social networking tools to support a community of practices among the stakeholders, virtual seminars, and a permanent virtual fair of results. A European Water Community (EWC) is being developed to promote exchanges between scientists and "end-users" of the FP6/FP7 water research project output. The limit of this approach is that it does not consider the seeding of stakeholder information into scientific concepts, but is to be considered more of an "add-on" step after research.

Another interesting example, though not related to mountain regions, is the AWARE project (see references) which sets out to explore how bridging the science-policy gap by involving citizen panels can help achieve sustainable water ecosystems management in Europe. According to the project outline, the state-of-the-art of the science-policy interface shows that currently efforts are insufficient for presenting results from research and demonstration projects in a form that policy makers can easily use, e.g. "science-digested" policy briefs. AWARE appropriately recognises that the consideration of research results by the policy-making community is not straightforward either, mainly for political reasons and difficulties in integrating the latest research developments into legislation. It suggests that there is potential for improved connectivity between actors. Emphasis is put on the role of the public to enlarge the concept of organisational learning to the wider concept of social learning by directly including societal aspects and the potential influence of research and policy development on different social groups (Solutions for Water, Marseille 6th WWF, 2012).

The lessons learned about engaging scientists show that the dialogue is often unidirectional, with policy-makers asking the scientists for advice but with scientists not always directing their research to answer policy questions (AWARE, 2011a). It was found that this dialogue works unevenly across different European countries and at different EU, national and local levels. A better connectivity between the body of research produced across the whole European Research Area and the advice provided to EU, national and local policymakers was suggested. Another barrier identified was that communicating scientific knowledge to a lay audience was a difficult task both for scientists and for citizens. Scientists would need public communication expertise to which they are often not used to and citizens may find that workshop attendance alone may not be enough to acquire a complete scientific knowledge. According to AWARE, a well-structured participatory process requires enough time and commitment from both sides. This may stand in contrast to the era of "fast" ICT processing.

The main recommendations of the project were to involve a team of scientists throughout the knowledge brokerage process and to engage 'scientific ambassadors' to communicate critical information to citizens, business representatives and policy-makers alike. In the context of mountain droughts and floods, the scientific ambassadors could communicate the differences between climate change and human impacts on hydrological extremes and the pitfalls of maladaptation to extremes, such as artificial snow production for winter tourism or unnecessary electricity consumption during summer droughts.

Another important element in the efficient application of ICT for early warning and adaptation is data transparency through environmental democracy. The recent EU Open Data Directive, in particular in the water sector, is a step towards this and the implementation of the UNECE Convention on Access to Information, Public Participation in Decision-Making and Access to Justice in Environmental Matters (Aarhus Convention, 1998). The latter is crucial since we are all living in one environment and depending on it (AWARE and Solutions for Water, 6th World Water Forum, 
Marseilles, 2012). In terms of legislation, it is interesting to analyse a non-EU country alpine country in this context. In Switzerland, environmental democracy is relevant to ICT in terms of accessibility of environmental information to all interested parties and to the general public, and on appeals to the Federal Supreme Court by environmental NGOs (OECD, 2007). However, at the time of the report, Switzerland has not yet ratified the Aarhus Convention (1998) and "practices concerning dissemination of information, access to the courts and public participation will need to be harmonised with this convention. Many cantons continue to restrict access to this information but draft legislation on public access to information is in the pipeline. In general, there are insufficient countrywide, harmonised monitoring and economic data and the use of indicators is still only partial. Efforts to set up a national environmental data network need to be continued. Although local Agenda 21 programmes now cover $30 \%$ of the population, there is a need to develop them further, especially in sparsely populated areas". On the other hand, "at the federal level, Swiss authorities provide the targeted public (cantons, communes, economic circles, the media and the general public) with a vast amount of information on environmental policy and its application (aids to implementation) in printed documents and in electronic format (OECD 2007)".

Nonetheless, and in contrast to floods, the 2003 drought in Switzerland did not have major impacts on policies. During droughts larger, temporary water withdrawals are possible, but residual flows must be established based on a balance between economic and ecological interests (OECD, 2007). "Following the drought in 2003 recommendations were made to the cantons, which are responsible for managing their own water: to improve the basis for decision-making, to elaborate a concept for possible future droughts and to ensure good communications among the authorities involved". And further - "Although Switzerland has abundant water resources, the 2003 heat wave had many consequences for water and water use. In watersheds without glacier coverage, especially in the Jura and on the Swiss plateau, 350 rivers dried up, either in stretches or totally, along a distance of $245 \mathrm{~km} ; 85000$ fish were found dead and real losses were probably much greater; 120000 fish had to be transferred to watercourses with sufficient flow; conflicts of interest arose between withdrawals for irrigation and for water protection. On the Rhine, navigation had to be restricted between Basel and Rotterdam. Warmer water also had harmful consequences (temperatures rose to as much as $26^{\circ} \mathrm{C}$ at a depth of 4 metres in the middle of the Rhine), causing the death of 50000 grayling in the Rhine downstream from Lake Constance. Conversely, in watersheds with glacier coverage watercourses carried an exceptional quantity of water due to heavy melting; mountain hydroelectric plants recorded a significant rise in output; and navigation companies in the northern Alps carried more passengers. At the end of the drought (the worst since 1947) federal authorities considered that no new legislative measures were required".
According to the 2007 OECD report, "environmental information systems have been strengthened in the past few years. National state of the environment reports sum up the state of the environment and the implementation of environmental policy for the benefit of decision makers and the public. In the future, the provision of data and of a series of online indicators will extend access to environmental information". Public participation is very well developed in Switzerland. Within the framework of a highly democratic system, there is very good co-operation among stakeholders including civil society (e.g. environmental NGOs, industry and farmer associations). The right to take part in referenda and public initiatives is highly developed and environmental democracy benefits from this right. However, public participation in environmental impact assessments (EIAs) is limited.

For France, the OECD environmental performance review of 2005 is not available online in English and only for reading via open ISBN in French (OECD, 2005). Unlike Switzerland, in France a drought management plan was put into place after the 2003 drought. It provides for national and basin monitoring committees to better anticipate needs and coordinate special measures to restrict water withdrawals and track watercourse temperatures, as extremes can cause substantial damage to aquatic environments.

However, no environmental impacts of the 2003 drought are listed, even though thermal cooling plants were allowed to reject warm water above the authorised temperatures. "In the case of nuclear plants, given that the severe weather had increased temperatures in some rivers by around $5^{\circ} \mathrm{C}$ above the averages recorded in the past $25 \mathrm{yr}$, several reactors had to be either shut down or operated on reduced load. In addition, high demand for electricity in response to the heatwave prompted operators to seek and obtain waivers to waste water discharge permit conditions".

Although the Aarhus Convention (1998) was ratified, it demands an improved public access to information, and an improved reactivity to public demand (OECD, 2005). "Public information on the right of access remains insufficient. Internet sites lack visibility for non-expert users, and a national website for environmental information could improve the efficiency of its use. The environmental data base could be improved. It is recommended that the coordination of information systems and coverage of quality of environmental data is improved and their accessibility and their use in the elaboration and monitoring of public policy reinforced. An improved coordination and cooperation of various water-related partners is required so that together they provide a national water information system in the internet. Access to information on the environment should be facilitated and public debates stimulated".

Concerning access to environmental information (OECD, 2005), this "refers to data collected or produced by a public agency in carrying out its mission. The information must be provided within one month after the request is made. After 
this deadline has passed, lack of a response from the agency concerned is deemed an implicit rejection of the request. Access to data may be refused on grounds of national security, confidentiality of certain public decisions and industrial or trade secrecy. Access may also be refused to documents being used in preparation for an administrative decision that has not yet been issued". Although amended, the current legislation for access to environmental information does not conform to the new EU directive on public access to environmental information (2003/4/EC) of 2005.

Nowadays, the situation of data accessibility is further complicated by political and economical interests. Manifestly, ICT can also be a strong tool for information distortion and disinformation in particular when concerning socioeconomic phenomena (Güvenen, 2012). For example, according to Martin (2012) in the French Alps, certain longterm meteorological data archives of EDF (French Hydroelectricity) with detailed snow data were destroyed. It therefore would seem that they were no longer seen as necessary for the hydro-electric industry that had sampled them and were seen as obsolete in the context of future climate change. Since Meteo France (Meteorological Service) has taken over the meteorological measuring network in the Alps, one may wonder whether the accuracy and density of the measurements of EDF were seen as competition and a further reason not to store and maintain them. Although extremely important in the context of climate change and future planning, ski resort operators did not attempt to retain the data either because of their politico-economic dimension with relation to the ski industry (Martin, 2012). It could have been that the decreasing snow heights and snow cover duration measured was contrary to their propaganda. Increasing winter droughts and water scarcity could menace the concept of economic sustainability. In this context, a situation with lacking data felt more secure and simpler to deal with. However, citizen voices show that there is a basic need for data and clarification: "Giving accurate information to citizens about an issue allows shedding light on it, allowing them to engage themselves to bringing a solution. Keeping us, citizens, in the dark prevents us from making full use of our ability to contribute to the decision making process." (citizen citation from AWARE publication, 2011a).

\section{Conclusions}

ICT is not straightforward in mountains due to lacking longterm and automated measuring series. In additions, many mountain catchments and socially-relevant sub-catchments are ungauged. Many mountain regions worldwide do not yet have full access to the internet, which encumbers the role of data transfer. Where economic and political interests and issues are pre-dominant, ICT may even serve to deform or even remove information. In many mountain catchments and mountain ranges, we are still far from designing and operating early warning systems in mountains and effected forelands. In addition, there is an over-emphasis on early warning of floods at the cost of droughts due to lacking awareness of the environmental and economic impacts of droughts. It is important to simplify ICT as much as possible for early warning and adaptation scenarios in mountains.

There is a strong need to integrate qualitative data to improve predictions and adaptation via the involvement of stakeholders. They can serve as climate change witnesses and local think tanks. Much can be learned from the methods and indicators used historically to describe droughts and floods before the onset of ICT. These indicators could be applied by local stakeholders, sophisticated by researchers and fed into simple, semi-conceptual ICT-based Early Warning Systems in the future. It is difficult to adapt to hydrological extremes without a proper data base and with policies missing at the EU level and national, yet many mountain stakeholders are already forced to adapt to rapid changes in hydrological extremes through common sense and spontaneous adaptation. At the same time, lack or obscurity of data has led to unintentional as well as intentional maladaptation to hydrological extremes, in particular to droughts.

Scientists should be implied and empowered much more strongly in helping to predict hydrological extremes and suggest adaptation strategies but in order to do so they have to become greater generalisers (thinking across disciplinary realms) and be willing to be reactive and proactive in obtaining continually up-dated local information from stakeholders and seeding interdisciplinary and inter-sectorial hypotheses on change.

Acknowledgements. Thanks go to many people that helped me put together the information in this article, in particular John Pomeroy (Saskatchewan University), Gianluca Botter (Padova University), Vladimir Aizen (Idaho University), Paula Alamano (Politecnico Torino), Wolfang Schoener (ZAMG), Ali Arda Sorman (Anadolu Univeristy, Eskisehir).

Edited by: A. Parodi

Reviewed by: G. Tartari and one anonymous referee

\section{References}

Aarhus Convention: The UNECE Convention on Access to Information, Public Participation in Decision-making and Access to Justice in Environmental Matters, available at:http://www. unece.org/env/pp/welcome.html (last access: 5 October 2012), Full Text in English: http://www.unece.org/fileadmin/DAM/env/ pp/documents/cep43e.pdf, 1998.

Allamano, P., Claps, P., and Laio, F.: Global warming increases flood risk in mountainous areas, Geophys. Res. Lett., 36, L24404, doi:10.1029/2009GL041395, 2009.

ARPA Piemonte: MeteoClima 50, Tendencies in long term precipitation, available at: www.arpa.piemonte.it (last access: 1 December 2012), 2012. 
AWARE: Project on connecting research, people and policy-makers in Europe to achieve sustainable water ecosystems management, June 2009-November 2011, available at: www.aware-eu.net (last access: 29 May 2012), 2012.

AWARE: FP7 project, Bridging the Science Policy Gap: Best Practices in Citizens' Participation, edited by: Sessa, C., Report D 4.3, 26 pp., 2011a.

AWARE: FP7 project, Identification of Key Stakeholders in the AWARE case study areas, edited by: Sessa, C., Report D 1.3, 19 pp., 2011 b.

Barriopedro, D., Fischer, E. M., Luterbacher, J., Trigo, R. M., and Garcia-Herrera, R.: The Hot Summer of 2010: Redrawing the Temperature Record Map of Europe, Science, 332, 220-224, 2011.

Bertolani, L., Bollasina, M., and Tartari, G.: Recent biennial variability of meteorological features in the Eastern Highland, Geophys. Res. Lett., 15, 2185-2188, 2000.

Botter, G., Basso, S., Porporato, A., Rodriguez-Iturbe, I., and Rinaldo, A.: Natural streamflow regime alterations: Damming of the Piave river basin (Italy), Water Resour. Res., 46, W06522, doi:10.1029/2009WR008523, 2010.

Brueckner, E. and Muret, E.: Les variations périodiques des glaciers, Sonder-Abdruck aus "Zeitschrift fuer Gletscherkunde", XIIme Rapport, 1906, IIL Band, 1907.

Brunetti, M., Maugeri, M., Nanni, T., Auer, I., Böhm, R., and Schöner, W.: Precipitation variability and changes in the greater Alpine region over the 1800-2003 period, J. Geophys. Res., 111, D11107, doi:10.1029/2005JD006674, 2006.

Casty, C., Wanner, H., Luterbacher, J., Esper, J., and Böhm, R.: Temperature and precipitation variability in the European Alps since 1500, Int. J. Climatol., 25, 1855-1880, doi:10.1002/joc.1216, 2005.

Climate-Adapt: European Climate Adaptation Platform, an initiative of the European Commission, aiming to support Europe in adapting to climate change, It is and helps users to access and share information, available at: http://climate-adapt.eea.europa. eu/ (last access: 1 June 2012), 2012.

Climwatadapt: EU project in Climate Adaptation - modelling water scenarios and sectorial impacts, available at: http://www. climwatadapt.eu/ (last access: 1 December 2012), 2012

Collective Awareness Platforms for Sustainability and Social Innovation (CAPS): ICT systems leveraging the emerging "network effect" by combining open online social media, distributed knowledge creation and data from real environments (Internet of Things), in order to create new forms of social innovation, available at: http://ec.europa.eu/information_ society/activities/collectiveawareness/index_en.htm (last access: 16 November 2012), 2012.

Commission of the European Communities: Adapting to climate change: Towards a European framework for action, White Paper, Report, 17 pp., 2009.

de Jong, C.: "Alp-Water-Scarce" Integrated River Basin Management in Mountains, INBO (International Network of Basin Organisations), Newsletter no. 17, 33 pp., 2008a.

de Jong, C: Alp-Water-Scarce, Water Management Strategies against Water Scarcity in the Alps, Unpublished Project Application Form approved and funded by the Alpine Space Interreg programme, 2008b. de Jong, C: Scientific Survey (WP8), ICT for Environmental Sustainability Concerning Key Area: "ICT for Sustainable Use of Natural Resources" ICT-Ensure, 7th FP, 224017, 1-30, available at: http://ict-ensure.tugraz.at/en/var/plain_site/storage/ original/application/_1440f05441910bdbec4bfe3a93999d51.pdf, 2009a.

de Jong, C.: Alp-Water-Scarce: Why we need water management in the Alps, A European project on Water Management Strategies against Water Scarcity in the Alps, The EGGS, EGU Newsletter, 26, 22-25, available at: http://www.the-eggs.org/data/eggs_26. pdf, 2009b.

de Jong, C.: Chapter 5.5. Savoy - balancing water demand and water supply under increasing climate change pressures, Regional Climate Change and Adaptation. The Alps facing the challenge of changing Water Resources, EEA (European Environment Agency) report, 8, 81-84, 2009c.

de Jong, C.: The Alps: a framework for Public Consultation on Water Management, INBO (International Network of Basin Organisations), Newsletter, 20, 44 pp., 2012.

de Jong, C. and Biedler, M.: Shadow of a drought, Euro. Sci. Technol., 14, 208-209, 2012.

de Jong, C. and Maurer, L.: Naturally Speaking, Sci. Technol., 5, 208-209, 2010.

de Jong, C., Ranzi, R., and Collins, D.: Climate and Hydrology in Mountain Areas, J. Wiley and Sons, Chichester, 315 pp., 2005.

de Jong, C., Lawler, D., and Essery, R.:. Mountain Hydroclimatology and Snow seasonality - perspectives on climate impacts, snow seasonality and hydrological change in mountain environments, Hydrol. Process., 23, 955-961, 2009.

de Jong, C., Gurer, I., Rimmer, A., Shaban, A., and Williams, M.: Chapter 5 Climate and Hydrology, Mediterranean Mountain Environments, edited by: Vogiatzakis, I., 1st Edn., J. Wiley \& Sons, 87-113, 2012a.

de Jong, C., Link, T., and Garen, D.: Predictions in Ungauged Basins, Working Group Report on Temperate Forests, IAHS, Putting PUB into Practice, Can. Water Resour. Assoc., 8 pp., submitted, 2012b.

Demuth, M. N. and Pietroniro, A.: The impact of climate change on the glaciers of the Canadian Rocky Mountain eastern slopes and implications for water resource-related adaptation in the Canadian prairies, "Phase I" - Headwaters of the North Saskatchewan River Basin; Climate Change Action Fund - Prairie Adaptation Research Collaborative, PARC Project P55, 111 pp., 2003.

DEWETRA: A real-time integrated system of risk forecasting, monitoring and prevention designed by scientists of the CIMA foundation on behalf of the Italian Civil Protection Department, available at: http://dewetra.cimafoundation.org/dewetra/ index_en.htm (last access: 5 June 2012), 2012.

Directive 2003/4/EC: of the European Parliament and of the Council of 28 January 2003 on public access to environmental information and repealing Council Directive 90/313/EEC OJ L 41, 14 February 2003, 26-32, available at: http://eur-lex.europa.eu/LexUriServ/LexUriServ.do?uri=OJ: L:2003:041:0026:0032:EN:PDF, 2003.

EEA: Water resources across Europe - confronting water scarcity and drought, edited by: Collins, R., Kristensen, P., and Thyssen, N., European Environment Agency Report Nr. 2, 60 pp., 2009a.

EEA: Regional climate change and adaptation - The Alps facing the challenge of changing water resources, Tech- 
nical report No 8/2009, European Environment Agency, Copenhagen, Denmark, available at: www.eea.europa.eu/ publications/alps-climate-change-and-adaptation-2009 (last access: 2 June 2012), 2009b.

EEA: Water resources: quantity and flows - SOER 2010 thematic assessment, The European Environment, State and Outlook 2010, edited by: Kristensen, P., 36 pp., 2010.

EGU Great Debate: The Role and Responsibilities of Geoscientists for Warning and Mitigation of Natural Disasters, available at: http://meetingorganizer.copernicus.org/EGU2012/ session/11193, 2012.

European Commission: Blueprint to safeguard Europe's water resources, available at: http://ec.europa.eu/environment/water/ blueprint/index_en.htm (last access: 3 June 2012), 2012.

European Water Partnership (EWP): European Dialogue Platform on Climate Change Adaptation: Water and Energy, available at: http://www.ewp.eu/activities/water-and-energy-climate-cca/ (last access: 5 October 2012), 2012.

Ev-K2-CNR: promotes scientific and technological research in mountain areas, particularly in the Hindu Kush - Karakorum Himalaya region (Nepal, Pakistan, China (Tibetan Autonomous Region) and India), available at: www.evk 2 cnr.org (last access: 6 October 2012), 2012.

Forel, F. A.: Commission Internationale des Glaciers, Les variations périodiques des glaciers, Discours préliminaire, Extrait des Archiven des sciences physiques et naturelles, XXXIV, Rey and Malavallon Sucsesseurs, Geneve, 22 pp., 1895.

Fountain, A. G. and Tangborn, W. V.: The Effect of Glaciers on Streamflow Variations, Water Resour. Res., 21, 579-586, 1985.

Fundetec: FP6 project, Comparison and Assessment of Funding Schemes for the Development of New Activities and Investments in Environmental Technologies, available at: http://www. fundetec.eu/ (last access: 15 November 2012), 2012.

García-Ruiz, J. M., López-Moreno, J. I, Vicente-Serrano, S. M, Lasanta, T., and Beguería, S.: Mediterranean water resources in a global change scenario, Earth Sci. Rev., 105, 121-139, 2011.

Güvenen, O.: Interactions of World-Regional Dynamics and the Role of Universities as a Catalyst, Proceedings of the 1st Winter Summit at the Anatolian Summit (WISAS). "Collaborative Projects on Tourism, Sports, Biodiversity and Global Change", Ataturk University, Erzurum, Turkey, 20-24, 2012.

Herman-Mercer, N., Schuster, P. F., and Maracle, K. B.: Indigenous Observations of Climate Change in the Lower Yukon River Basin, Alaska, Human Organization, 70, 244-252, 2011.

Hill, M.: Converging threats: assessing socio-economic and climate impacts on water governance, Int. J. Climate Change Strat. Manage., 2, 242-263, 2010.

Hill, M.: Characterising adaptive capacity in water governance arrangement in the context of extreme events, in: Climate Change and the Sustainable Management of Water Resources, edited by: Leal Filho, W., Springer Verlag, Berlin, 1-22, 2011.

Hill, M., Wallner, A., and Furtado, J.: Reducing vulnerability to climate change in the Swiss Alps: a study of adaptive planning, Climate Policy, 10, 70-86, 2010.

Hopkinson, C. and Young, G.: The effect of glacier wastage on the flow of the Bow River at Banff, Alberta, 1951-1993, Hydrol. Process., 12, 1745-1762, 1998.

Hunsaker, C. T., Whitaker, T. W., and Bales, R. C.: Snowmelt runoff and water yield along elevation and temperature gradients in Cal- ifornia's southern Sierra Nevada, J. Am. Water Resour. Assoc., 1-12, doi:10.1111/j.1752-1688.2012.00641.x, 2012.

ICT-Ensure: a leading support action for building a European Research Area in the field of "ICT for Environmental Sustainability", with the objective to foster the usage of new technologies as well as supporting the global community in their collaboration to preserve the environment in the long term, available at: http: //ict-ensure.tugraz.at/en/index.php (last access: 1 June 2012), 2012.

IMPETUS:Integrated management project for efficient and sustainable water use in Africa, available at: www.impetus.uni-koeln.de (last access: 1 June 2012), 2012.

IP3 Research Basins: (Improving Processes \& Parameterization for Prediction in Cold Regions Hydrology), available at: http://www. usask.ca/ip3/basins.php (last access: 3 May 2012), 2012.

IPCC: Managing the risks of extreme events and disasters to advance climate change adaptation, available at: http://ipcc-wg2. gov/SREX/images/uploads/SREX-All_FINAL.pdf (last access: 1 June 2012), 2012.

Jones, J. A., Creed, I. F., Hatcher, K. L., Warren, R. J., Adams, M. B., Benson, M. H., Boose, E., Brown, W. A., Campbell, J. L., Covich, A., Clow, D. W., Dahm, C. N., Elder, K., Ford, C. R., Grimm, N. B., Henshaw, D. L., Larson, K. L., Miles, E. S., Miles, K. M., Sebestyen, S. T., Spargo, A. T., Stone, A. B., Vose, J. M., and Williams, M. W.: Ecosystem Processes and Human Influences Regulate Streamflow Response to Climate Change at Long-Term Ecological Research Sites, Science, 62, 390-404, 2012.

Koboltschnig, G. R., Schoener, W., Holzmann, H., and Zappa, M.: Glaciermelt of a small basin contributing to runoff under the extreme climate conditions in the summer of 2003, Hydrol. Process., 23, 1010-1018, 2009.

Lapp, S., Byrne, J., Townshend, I., and Kienzle, S.: Climate warming impacts on snowpack accumulation in an alpine watershed, Int. J. Climatol., 25, 521-536, doi:10.1002/joc.1140, 2005.

Martin, P.: Regard désabusé sur la neige, les stations et leur avenir, (A disabused view on snow, ski resorts and their future), Mountain Wilderness, 90, 16-17, 2012.

Marty, Ch. and Meister, R.: Long-term snow and weather observations at Weissfluhjoch and its relation to other high-altitude observatories in the Alps, Theor. Appl. Climatol., 110, 573-583, doi:10.1007/s00704-012-0584-3, 2012.

Mazepa, V., Shiyatov, S., and Devi, N.: Chapter 19., ClimateDriven Change of the Stand Age Structure in the Polar Ural Mountains, available at: http://cdn.intechopen.com/pdfs/19851/ InTech-Climate_driven_change_of_the_stand_age_structure_in_ the_polar_ural_mountains.pdf, last access: 1 June 2012.

NASA: available at: www.neo.sci.gsic.nasa.gov, last access: 3 May 2012.

OECD: Environmental Performance Reviews France, OECD Publishing, 251 pp., 2005.

OECD: Environmental Performance Reviews Switzerland, OECD Publishing, 251 pp., 2007.

Parodi, A., Boni, G., Ferraris, L., Rudari, R., and Siccardi, F.: Hydro-Meteorology Research and ICT at CIMA Foundation: DEWETRA and DRIHMS experiences, AGU, Fall Meeting 2010, abstract \#H53H-01, 2010.

Pfister, C.: Wetternachhersage, 500 Jahre Klimavariation und Naturkatastrophen (1496-1995), Haupt, Bern, 304 pp., 1999. 
Poff, N. L., Richter, B. D., Arthington, A. H., Bunn, S. E., Naiman, O. J., Kendy, E., Acreman, M., Apse, C., Bledsoe, B. P., Freeman, M. C., Henriksen, J., Jacobson, R. B., Kennen, J. G., Merritt, D. M., O'Keefe, Olden, J. H. J. D., Rogers, K., Tharme, R. E., and Warner, A.: The ecological limits of hydrologic alteration (ELOHA): a new framework for developing regional environmental flow standards, Freshwater Biol., 55, 147-170, 2010.

Rampazzo, R. and Vecellio, C.: Alp-Water-Scarce - Strategie di gestione dell' acqua contro la Scarsità d'Acqua nelle Alpi: il sito pilota del Fiume Piave, (Alp-Water-Scarce - Water management strategies for limited water supply in the Alps: the Piave River pilot site), Youth Initiative, Initiative of the Institute of Research on Water Resources of the CNR - National Research Center, Assetto Istituzionale nel governo della risorsa idrica: il ruolo dello stato e le competenze delle regioni, 1-3, available at: http://www.hydrica.org/pdf/Convegni\%20Hydrica\%202011/ Venerdi\%201\%20Aprile\%202011/Iniziativa\%20Giovani/ AWS-PIAVE-\%20Rampazzo-Vecellio.pdf,2011.

Raymond, C. M., Fazey, I., Reed, M. S., Stringer, L. C., Robinson, G. M., and Evely, A. C.: Integrating local and scientific knowledge for environmental management, J. Environ. Manage., 91, 1766-1777, 2010.

Robins, J. S., Kelly, L. L., and Hamon, W. R.: Reynolds Creek in southwest Idaho: an outdoor hydrologic laboratory, Water Resour. Res., 1, 407-413, 1965.

Scalet, F. and Pergher, P.: The basin of the River Noce study of the water uses and water balance, Water Management Strategies against Water Scarcity in the Alps, Poster presentation, available at: https://www.sbg.ac.at/zgis/alpwaterscarce/03_Work/ WP03_InformationAndPublicity/3.2_AWS_Website_Documents/ Internal\%20Area/Conference_Megeve/Poster_9.pdf, 2010.

Serquet, G., Marty, C. H., Dulex, J. P., and Rebetze, M.: Seasonal trends and temperature dependence of the snowfall/precipitation day ratio in Switzerland, Geophys. Res. Lett., 38, L07703, doi:10.1029/2011GL046976, 2011.

Shahgedanova, M., Nosenko, G., Khromova, T., and Muraveyev, A.: Glacier shrinkage and climatic change in the Russian Altai from the mid-20th century: An assessment using remote sensing and PRECIS regional climate model, J. Geophys. Res., 115, D16107, doi:10.1029/2009JD012976, 2010.

SHARE: available at: Stations at High Altitude for Research on the Environment, www.share.everest.com, last access: 1 June 2012.

Soboll, A. and Schmude, J.: Simulating Tourism Water Consumption Under Climate Change Conditions Using Agent-Based Modeling: The Example of Ski Areas, Ann. Assoc. Am. Geogr., $1011-18,2011$.
Solutions for Water, 6th World Water Forum, Marseilles, available at: http://www.solutionsforwater.org/solutions/awarebridging-the-science-policy (last access: 1 June 2012), 2012.

Tartari, G., Vuillermoz, E., Manfredi, E., and Toffolon, R.: CEOP High elevation initiative, GEWEX News, 19, 4-5, 2009.

Veneto Regional Agency: available at: http://www.arpa.veneto.it/, 2012.

Vuillermoz, E., Verza, G. P., Toffolon, R., Tartari, G., Lami, A., and Bonasoni, P: The first SHARE - Automatic Weather Station (AWS) in Africa, Mt. Rwenzori (Uganda), Poster at GEWEX conference, available at: http://gewex.org/2009Conf_ gewex_posters/Verza_GP1-25.pdf (last access: 3 June 2012), 2009.

Wasser App: a new water appliance for monitoring individual household water use via mobile phone in the town of Villach, Austria, available at: http://wasserapp.com/, http://www.villach. at/inhalt/72214_85463.asp, last access: 3 June 2012.

WaterDiss2.0: The project' aims are to speed-up the transfer of research outputs to water management institutions, available at: www.waterdiss.eu, last access: 3 June 2012.

Wiegandt, E.: Mountains: Sources of Water, Sources of Knowledge, Springer, 384 pp., 2008.

Wiegandt, E. and Lugon, R.: Challenges of living with glaciers in the Swiss Alps, Past and Present, in: Darkening Peaks: Glacier Retreat, Science and Society, edited by: Orlove, B., Wiegandt, E., and Luckmann, B., Berkeley, Univ. of California Press, 3348, 2008 .

Williams, M. W., Losleben, M., Caine, N., and Greenland, D.: Changes in climate and hydrochemical responses in a highelevation catchment in the Rocky Mountains, USA, Limnol. Oceanogr., 41, 939-946, 1996.

WISE: is a gateway to information on European water issues. It includes the European Flood Alert System (EFAS) - http: //floods.jrc.ec.europa.eu/efas-flood-forecasts.html and the European Drought Observatory (EDO) http://desert.jrc.ec.europa.eu/, available at: http://water.europa.eu/, last access: 3 June 2012.

Wohl, E. E.: Mountain Rivers, Water Resources Monograph 14, AGU, Washington DC, 320 pp., 2000.

Wu, S., Yao, Z., Huang, H., Liu, Z., and Liu, G.: Responses of glaciers and glacial lakes to climate variation between 1975 and 2005 in the Rongxer basin of Tibet, China and Nepal, Regional Environ. Change, 12, 887-898, doi:10.1007/s10113-012-0302-9, 2012.

WMO: available at: www.wmo.int, last access: 3 June 2012.

Yilmaz, A. G. and Imteaz, M. A.: Impact of climate change on runoff in the upper part of the Euphrates basin, Hydrol. Sci. J., $56,1265-1279,2011$. 